\title{
Corporate Governance and Firm Performance: Evidence From the ADRs of Tiger Cub Economies
}

\author{
Lee-Hsien Pan (Corresponding author) \\ School of Business \\ State University of New York-Geneseo, USA \\ E-mail: pan@geneseo.edu \\ Shuo Chen \\ School of Business \\ State University of New York-Geneseo, USA \\ Chieh-Chung Wu \\ Department of Accounting and Information Technology \\ National Chung Cheng University, Chia Yi, Taiwan \\ K. C. Chen \\ Craig School of Business \\ California State University-Fresno, USA
}

Received: February 27, 2019

Accepted: March 25, 2019 Published: March 27, 2019

doi:10.5296/ijafr.v9i1.14578

URL: https://doi.org/10.5296/ijafr.v9i1.14578

\begin{abstract}
This paper examines the effects of cross listing and Sarbanes-Oxley Act (SOX) on corporate governance and firm performance of the cross-listed firms from four Tiger Cub Economics: Indonesia, Malaysia, Philippines, and Thailand. We find that these non-U.S. firms that list their shares as American Depositary Receipts (ADRs) experience an improvement in
\end{abstract}


corporate governance and a decrease in firm performance after issuing ADRs in the U.S. However, SOX appears to be effective in enhancing firm performance for these ADRs, though it has little impact on improving corporate governance.

Keywords: American Depositary Receipts (ADRs), Cross-Listing, Sarbanes-Oxley Act (SOX), Corporate governance, Firm performance, Tiger cub economies

JEL Classification: G34, G38, M48

\section{Introduction}

American Depositary Receipts (ADRs) are negotiable securities that represent shares of a non-U.S. company traded in the U.S. financial markets. ADRs allow U.S. investors to invest in non-U.S. companies directly and provide non-U.S. companies with a channel of raising capital or establishing trading presence in the U.S. According to J.P. Morgan, by the end of August 2014, there are 4,767 ADRs traded on U.S. markets, compared with 2,314 ADRs by the end of 2010. Part of the reasons of increased popularity in ADRs among U.S. investors in the past years is that it is convenient for U.S. investors to trade securities of foreign companies without worrying about the exchange rate risk and higher transaction costs. In addition, foreign firms choosing to issue ADRs in the U.S. may benefit from lower information asymmetry (Alexnader et al., 1987; Aggarwal et al, 2012), reduced agency problems (Lel and Miller, 2008), improved disclosure standards (Domowitz et al., 1997), enhanced governance practices (Doidge et al, 2009), and increased firm performance (Karolyi, 1998).

Existing literature suggests that corporate governance and firm performance of non-U.S. firms cross-listed on U.S. markets may improve after cross listing because these firms are subject to the stringent U.S. investor protection laws and regulations (Karolyi, 1998; Miller, 1999; Stulz, 1999; Coffee, 1999, 2002; Doidge et al., 2004). However, few studies have focused on the impacts of cross listing on corporate governance and firm performance of non-U.S. firms from emerging economies where investor protections are relatively poor compared with those of advanced economies. La Porta et al. (2000) argue that corporate governance plays an important role in the development of financial markets and the improvement of firm value, especially for firms from emerging economies. Doidge et al. (2004) show that growth opportunities are more valued for firms choosing to cross list in the U.S., especially for those from countries with weaker investor protections. If corporate governance and growth opportunities are more influential for cross-listed firms from emerging economies where investor protections are weaker, examining post-ADR effects on corporate governance and firm performance of firms from emerging economies may shed light on the differential impacts of cross listing between firms in emerging markets and advanced economies.

Furthermore, non-U.S. firms choosing to cross-list on U.S. stock exchanges are bound not only by the listing requirements but also by the corporate governance rules and regulations (i.e., SOX) of the U.S. markets. The extent to which the U.S. rules and listing requirements affect the corporate governance and firm performance of the cross-listed firms may depend 
on the types of ADRs (Note 1). Investigating the effects of cross listing and SOX on corporate governance and firm performance may lead to further understanding on the effectiveness and enforcement of different laws and regulations imposed on various types of ADRs, which are of value to investors and policy makers.

Our results suggest that Indonesian, Malaysian, Philippine, and Thailand's firms have experienced an improvement in corporate governance after cross listing on U.S. markets. Post-ADR firm performance has worsened, though this outcome occurs concurrently over the financial crisis period and its aftermath. The evidence also shows that SOX appears to be effective in improving firm performance, despite the high compliance costs associated with the improvement of financial disclosures and the prevention of fraudulent accounting activities.

The contributions of this paper are twofold. First, bonding hypothesis suggests that corporate governance and firm performance can be improved after cross-listing (Coffee, 1999 and 2002; Stulz, 1999). Our results suggest that while non-U.S. firms choosing to cross-list in U.S. may experience an improvement in corporate governance after cross listing, they may exhibit a decrease in firm performance if their home countries are from emerging economies. Second, prior studies document that SOX may improve corporate governance but decrease firm performance (Valenti 2008; Berger et al. 2005). Our results suggest that SOX appears to be effective in enhancing firm performance for the ADRs in the Tiger Cub Economies, though its influence on improving corporate governance is insignificant. Our findings suggest that the domiciles and the types of the ADRs may affect the effectiveness and enforcement of U.S. laws and regulations on corporate governance and firm performance of cross-listed firms.

The remainder of the paper is organized as follows. Section 2 provides related literature and develops hypotheses for testing. Section 3 explains the data and methodology. Section 4 discusses the empirical results and Section 5 concludes the paper.

\section{Literature Review and Hypotheses Development}

\subsection{Literature Review}

Literature regarding the motivations of non-U.S. firms listing their shares on U.S. stock exchanges can be classified into the corporate governance and firm performance. Thus, we discuss literature review by breaking it into corporate governance and firm performance sub-categories, respectively.

\subsubsection{Corporate Governance}

Scholars have argued that non-U.S. firms benefit from cross listing on U.S. stock markets for the following reasons. Information disclosure hypothesis argues that cross-listed firms send a positive signal about their commitment to good corporate governance because these firms need to comply with the rules and regulations set by Securities and Exchange Commission (SEC). Ball Hail and Vasvari (2018) document that the effort to improve corporate governance is valuable for potential investors because it signals that these firms are willing to mitigate information asymmetries and agency problems. 
Reputational bonding hypothesis states that foreign firms may try to build a positive reputation among potential investors and customers by bonding themselves to the stringent rules and regulations of the U.S. market. Wójcik, Clark and Bauer (2005) find that cross-listed firms tend to enjoy a better reputation for good corporate governance than their non-cross-listed counterparts do. Licht (2003) and Siegel (2005) argue that while U.S. laws and regulations may not be effective for non-U.S. cross-listed foreign firms, these firms can build their reputation for greater transparency through voluntary information disclosure. Using U.S. Supreme Court Case as a natural experiment, Licht et al (2018) test the legal bonding hypothesis and they find that foreign firms cross-listed on U.S. stock exchanges may facilitate good reputation. Their results are consistent with reputational bonding. Thus, gaining a good reputation in corporate governance through reputational bonding has been a major motivation for listing shares in the U.S.

Market monitoring mechanism hypothesis contends that good corporate governance can be achieved not only by the stringent rules and regulations of the U.S., but also by the market monitoring mechanisms overseas. Benos and Weisbach (2004) find that non-U.S. cross-listed firms would attract a larger pool of professional analysts who can provide more accurate and credible information for investors. Lee and Valero (2010) analyze the dispersion of analyst recommendations on non-U.S. cross-listed foreign firms between their pre-listing and post-listing on U.S. stock exchanges. They find an increase in analyst coverage across all four types of ADR programs. By cross listing in the U.S., these firms would operate in a more competitive market environment, which can improve the quality of corporate governance.

\subsubsection{Firm Performance}

The benefits of firm performance for firms cross-listed in U.S. have been well documented in the literature. Market segmentation hypothesis claims that cross-listed firms, compared with their non-cross-listed counterparts, can reduce the cost of capital by gaining access to U.S. capital market more easily and cheaply because these ADRs can lower barriers to global investing (Alexander, Eun, and Janakiramanan, 1988; Foerster and Karolyi, 1999; Eaton, Nofsinger and Weaver, 2007; Ball, Hail, and Vasvari, 2018).

Another hypothesis that supports the reduction of cost of capital is analysts following hypothesis. It argues that cross-listed firms tend to attract more analysts following, which reduces cost of capital and enhances firm value. Pagano, Roell and Zechner (2002) find that European cross-listed high-tech firms, compared with their non-cross-listed counterparts, are more likely to attract more professional analysts and institutional investors, which lead to a reduction in information asymmetry between shareholders and the companies. As a result, these companies can gain access to lowest cost of capital needed for a new product development. Lang, Lins, and Miller (2003) investigate the relation between information environment of non-U.S. firms and their cross-listing in the U.S. They document that these non-U.S. cross-listed foreign firms experience greater analyst coverage and increased forecast accuracy compared with their non-cross-listed counterparts. By cross-listing on U.S. exchanges, these firms exhibit increased coverage and forecast accuracy, which enhance market valuations. 
Investor recognition hypothesis contends that cross-listed firms can gain investor recognition because these firms need to comply with the accounting rules and listing regulations of the U.S. Merton (1987) argues that investors prefer to invest in cross-listed foreign companies because these companies signal a higher level of information disclosure and transparency. Using analyst coverage and media attention as proxies, Baker et al. (2002) show that cross-listed firms exhibit an increase in visibility after listing their shares on the New York Stock Exchange or the London Stock Exchange. Their results suggest that increased analyst coverage and media attention help reduce the cost of equity capital after cross-listings. Accordingly, these cross-listed firms tend to experience an increase in firm performance.

\subsection{Hypotheses Development}

The listing requirement for foreign firms choosing to cross-list in the U.S., and the rules and regulations associated with SOX could possibly affect the corporate governance and firm performance of the companies listing their shares as ADRs. In this subsection, therefore, we develop testable hypotheses based on the two events: cross listing and SOX, respectively.

\subsubsection{Cross-Listings}

The most important evidence in prior literature regarding the impact of cross listing on a firm's corporate governance is bonding hypothesis, which is proposed by Coffee (1999, 2002), and Stulz (1999). Bonding hypothesis supports a global convergence in corporate governance and argues that any foreign firms cross listing their shares on U.S. stock exchanges can prevent insiders from engaging fraud activities. Their findings suggest that the stringent U.S. laws and regulations help deter insiders from expropriating minority shareholders and improve corporate governance of the firms cross-listed in the U.S. Following bonding hypothesis, Reese and Weisbach (2002), Doidge (2004), Doidge et al. (2004, 2009) and Lel and Miller (2008) find that foreign firms cross-listed on the markets with stricter rules and regulations than their home countries may limit their managers' and insiders' expropriation of minority shareholders. Their evidences support the bonding hypothesis that cross-listed foreign firms may experience an improvement in corporate governance after cross listing on U.S. stock markets.

In addition to the improvement in corporate governance, bonding hypothesis further suggests that cross-listed foreign firms can better protect investors' rights and broaden shareholder and customer bases, which lead to lower costs of capital and increased competitiveness and valuation. Doidge et al. (2004) examine the reasons why foreign firms listed in the U.S. worth more and they find that cross-listed firms are more likely to limit the expropriation of minority shareholders and thereby increase the firms' ability to capitalize on growth opportunities. They find that such growth opportunities tend to be move valued by cross-listed firms especially from countries with weaker shareholder protections. Given the above-mentioned discussions, we establish our first hypothesis with two corollaries:

$\mathrm{H}_{1 \mathrm{a}}$ : After issuing ADRs, Indonesian, Malaysian, Philippine, and Thailand's firms exhibit an improvement in corporate governance.

$\mathrm{H}_{1 \mathrm{~b}}$ : After issuing ADRs, Indonesian, Malaysian, Philippine, and Thailand's firms exhibit an 
improvement in firm performance.

\subsubsection{Sarbanes-Oxley Act (SOX)}

In response to a number of high profile corporate and accounting scandals such as Enron and WorldCom which cost investors billions of dollars, the United States Congress passed the Sarbanes-Oxley Act (SOX) to protect investors from corporate fraudulent activities in 2002. The contents of SOX include 1) Establishing an independent agency, the Public Company Accounting Oversight Board (PCAOB) to conduct financial audits on public companies, 2) Strengthening the internal control policies of public companies, 3) Holding CEO and CFO accountable for the validity of financial statements. Studies have shown that the quality of corporate governance for U.S. companies has improved after the passage of SOX. For example, Valenti (2008) examines whether U.S. corporations have improved their board transparency after the passage of SOX and she finds evidence that companies have strengthened the monitoring ability of the boards after SOX. However, Berger et al. (2005) find that SOX may cause a decrease in firm performance because of the higher costs of compliance and information disclosure. Given the above-mentioned discussions, we establish our second hypothesis with two corollaries:

$\mathrm{H}_{2 \mathrm{a}}$ : After the passage of SOX, Indonesian, Malaysian, Philippine, and Thailand's firms listing their shares as ADRs exhibit an improvement in corporate governance.

$\mathrm{H}_{2 \mathrm{~b}}$ : After the passage of SOX, Indonesian, Malaysian, Philippine, and Thailand's firms listing their shares as ADRs exhibit a decline in firm performance.

\section{Data and Methodology}

\subsection{Data}

We collect data of ADRs issued by firms of Indonesia, Malaysia, Philippines, and Thailand in the U.S. markets between 2000 and 2013. Although the cross listings in the US markets from these countries began as early as 1983, we exclude data before 2000 due to data availability. The removal of the data before 2000 should not pose any problem on the completeness of the sample because less than $20 \%$ of data occurred by year 2000. As reported in Table 1, we obtain 179 ADRs for our initial sample. We then remove 29 ADRs in financial and insurance industries due to the incomparability of financial statements arising from the additional regulations in these sectors. After excluding 30 ADRs with missing information, the final sample contains 120 ADRs and 930 firm-year observations. With regard to the types of ADRs, 117 out of 120 (97.5\%) ADRs are Level I, and 94 out of 117 (80.34\%) Level I ADRs are unsponsored. It indicates that the majority of our sample are Level I ADRs, which do not need to commit themselves to the strict disclosure rules and regulations as Level II and Level III ADRs do (Boubarkri et al. 2010). 
Table 1. Sample selection

\begin{tabular}{llllll}
\hline & Level I & \multicolumn{5}{c}{ Level II } & Level III & Total \\
\hline & Unsponsored & Sponsored & & & \\
\hline Initial data & 133 & 43 & 1 & 2 & 179 \\
\hline Finance and insurance sector & 25 & 4 & 0 & 0 & 29 \\
\hline Missing information & 14 & 16 & 0 & 0 & 30 \\
\hline Final sample & 94 & 23 & 1 & 2 & 120 \\
\hline Number of observations & 749 & 159 & 9 & 13 & 930 \\
\hline
\end{tabular}

Table 2 presents the distribution of the sample ADRs by type, and by industry according to the Global Industry Classification Standard (GICS). Among the 120 ADRs, energy, materials, and telecommunications services industries represent about $23 \%, 15 \%$, and $9 \%$ of the total firms, respectively. The remaining 53\% of the sample firms are spread across the other 14 industries. Only three companies list their shares under Level II and Level III ADR programs and they are all from telecommunication services industry (Note 2).

Table 2. ADRs by industry and type

\begin{tabular}{|c|c|c|c|c|c|c|c|}
\hline \multirow{2}{*}{ Industry } & \multirow{2}{*}{ GICS } & \multicolumn{4}{|c|}{ ADR type } & \multirow{2}{*}{ Total } & \multirow{2}{*}{ Percentage $(\%)$} \\
\hline & & Level I & Level II & Level III & Rule 144A & & \\
\hline Energy & 1010 & 28 & & & & 28 & 23.33 \\
\hline Materials & 1510 & 18 & & & & 18 & 15.00 \\
\hline Capital goods & 2010 & 2 & & & & 2 & 1.67 \\
\hline Commercial \& professional services & 2020 & 6 & & & & 6 & 5.00 \\
\hline Transportation & 2030 & 7 & & & & 7 & 5.83 \\
\hline Automobiles and components & 2510 & 3 & & & & 3 & 2.50 \\
\hline Consumer services & 2530 & 9 & & & & 9 & 7.50 \\
\hline Media & 2540 & 5 & & & & 5 & 4.17 \\
\hline Retailing & 2550 & 8 & & & & 8 & 6.67 \\
\hline Food \& staples retailing & 3010 & 3 & & & & 3 & 2.50 \\
\hline Food, beverage $\&$ tobacco & 3020 & 6 & & & & 6 & 5.00 \\
\hline Household \& personal products & 3030 & 2 & & & & 2 & 1.67 \\
\hline Health care equipment \& services & 3510 & 1 & & & & 1 & 0.83 \\
\hline Pharmaceuticals, biotechnology \& life sciences & 3520 & 3 & & & & 3 & 2.50 \\
\hline Real estate & 4040 & 8 & & & & 8 & 6.67 \\
\hline Technology hardware \& equipment & 4520 & 1 & & & & 1 & 0.83 \\
\hline Telecommunication services & 5010 & 8 & 1 & 2 & & 11 & 9.17 \\
\hline Total & & 117 & 1 & 2 & & 120 & 100 \\
\hline
\end{tabular}

\subsection{Methodology}

To present an overview about corporate governance and firm performance of the Indonesian, Malaysian, Philippine, and Thailand's ADRs, we use summary statistics for the full sample. Then, we use T-tests to examine the differences in corporate governance and firm performance between (1) pre-cross-listing and post-cross-listing subsamples, and (2) pre-SOX and post-SOX subsamples, respectively. Finally, we use the following multivariate 


\section{MInstitute ${ }^{\text {Mink }}$}

International Journal of Accounting and Financial Reporting

ISSN 2162-3082

2019, Vol. 9, No. 1

regression model to examine the effects of the two events on the performance of these ADRs.

Performance $_{t}=f\left(\right.$ Corporate Governance $_{t-1}$, Firm Characteristics ${ }_{t-1}$, Events, Controls $)$

where performance stands for return on assets (ROA), and Tobin's Q (Tobin's Q) at time t, respectively; corporate governance includes board size (BOARD SIZE), ratio of independent directors on board (INDEP RATIO), CEO duality (CEO DUALITY), CEOs' educational background in business (CEO EDUCATION), insider ownership (INSIDER OWN), and big 4 auditing (BIG 4) at time t-1, respectively; firm characteristics are firm size (LNASSET) and leverage (LEVERAGE) at time $\mathrm{t}-1$, respectively; events represent ADR listing and SOX, respectively; controls are the year and industry fixed effects used in the regression analysis. For conciseness, we show the detailed explanation of the variables in Table 3.

Table 3. Variable definitions

\begin{tabular}{|c|c|c|}
\hline Variable & Abbreviation & Definition \\
\hline \multicolumn{3}{|l|}{ Governance Measures } \\
\hline Board size & BOARD SIZE & Number of directors on the board \\
\hline Ratio of independent directors & INDEP RATIO & Number of independent directors divided by board size \\
\hline CEO duality & CEO DUALITY & $\begin{array}{l}\text { Dummy variable, equals } 1 \text { if CEO is also chairman of the board } \\
\text { and } 0 \text { otherwise }\end{array}$ \\
\hline CEO education background & CEO EDUCATION & $\begin{array}{l}\text { Dummy variable, equals } 1 \text { if CEO has business education } \\
\text { background and } 0 \text { otherwise }\end{array}$ \\
\hline Insider ownership & INSIDER OWN & $\begin{array}{l}\text { Shares owned by management divided by total outstanding } \\
\text { shares }\end{array}$ \\
\hline Big 4 auditing & BIG 4 & $\begin{array}{l}\text { Dummy variable, equals } 1 \text { if audited by a Big } 4 \text { accounting firm } \\
\text { and } 0 \text { otherwise }\end{array}$ \\
\hline \multicolumn{3}{|l|}{ Firm characteristics } \\
\hline Return on assets & ROA & Net income divided by book value of assets \\
\hline Tobin's Q & TOBIN'S Q & $\begin{array}{l}\text { (Book value of total assets - book value of equity + market } \\
\text { value of equity)/book value of total assets }\end{array}$ \\
\hline \multicolumn{3}{|l|}{ Event variable } \\
\hline ADR listing & ADR & $\begin{array}{l}\text { Dummy variable, equals } 1 \text { for years after listing, } 0 \text { for years } \\
\text { before listing, list year is excluded }\end{array}$ \\
\hline SOX & SOX & $\begin{array}{l}\text { Dummy variable, equals } 1 \text { for years after SOX, } 0 \text { for years } \\
\text { before SOX, year } 2002 \text { is excluded }\end{array}$ \\
\hline \multicolumn{3}{|l|}{ Control variables } \\
\hline Firm size & LNASSET & Natural log of book value of assets \\
\hline Leverage & LEVERAGE & Debt value divided by book value of equity \\
\hline Industry dummies & INDUSTRY DUMMY & Dummy variable, based on GICS categories \\
\hline Year dummies & YEAR DUMMY & Dummy variable, from year 2000 to year 2013 \\
\hline
\end{tabular}

\section{Empirical Results}

\subsection{Summary Statistics of the Tiger Cub ADRs}

Table 4 presents the descriptive statistics of the governance variables, firm characteristics, and performance measures. The average number of directors on the board (BOARD SIZE) in our sample is 9.86 for the four Tiger Cub ADRs. The board size is appropriate as suggested by Lipton and Lorsch (1992) who recommend a preferred board size of eight to ten members on the board. The range of board size varies from 3 to 23, with a standard deviation of 3.55. The difference in board size explains the variations in firm size (LNASSET) and leverage ratio (LEVERAGE) as larger firms and firms relying more on debt may need some guidance from the board (Coles et al., 2008). 
Table 4. Descriptive statistics

\begin{tabular}{|l|c|c|c|c|c|}
\hline \multicolumn{1}{|c|}{ Variable } & $\mathrm{N}$ & Mean & Standard deviation & Minimum & Maximum \\
\hline Corporate governance & & & & & \\
\hline$\quad$ Board size & 879 & 9.86 & 3.55 & 3 & 23 \\
\hline Indep ratio & 868 & 0.37 & 0.15 & 0 & 1 \\
\hline CEO duality & 895 & 0.12 & 0.33 & 0 & 1 \\
\hline CEO education & 794 & 0.55 & 0.50 & 0 & 1 \\
\hline Insider own & 610 & 0.10 & 0.19 & 0 & 1 \\
\hline Big 4 & 885 & 0.86 & 0.35 & 0 & 1 \\
\hline Firm characteristics & & & & & \\
\hline$\quad$ Lnasset & 820 & 20.87 & 2.09 & 9.62 & 28.79 \\
\hline$\quad$ Leverage & 873 & 1.25 & 1.12 & 0.00 & 9.85 \\
\hline Firm performance & & & & & \\
\hline ROA & 876 & 0.09 & 0.16 & -0.72 & 3.78 \\
\hline Tobin's Q & 839 & 1.84 & 1.58 & 0.15 & 9.97 \\
\hline
\end{tabular}

On average, the percentage of independent directors on board (INDEP RATIO) is 37\%, which is low compared with $65 \%$ of independent directors sitting on board for IPO firms in the U.S. (Cheng, 2008). Lorsch and Maclver (1989) argue that higher percentage of powerful independent directors on board tend to increase board's monitoring power and reduce agency costs. This suggests that the ADR firms from the Tiger Cub economies have room to increase the ratio of independent directors on the board. The average percentage of CEOs who serve as chairmen of the board (CEO DUALITY) is $12 \%$ for sample firms. Baliga et al. (1996) argue that agency costs are lower in the absence of CEO duality, while Brickley et al. (1997) suggest that CEO duality may help avoid the potential conflict between CEO and chairman and thus shorten the decision-making process. The lower CEO duality suggests that these ADRs need to find a balance between lower CEO duality that lowers agency costs and higher CEO duality that makes decision-making more efficient.

Fifty-five percent of the CEOs in our sample have educational background in business (CEO EDUCATION), though Alice et al. (2000) report that business educational background does not have positive relationship with firm value. On average, insiders (INSIDER OWN) from the sample ADRs own $10 \%$ of the total shares of the company. Jensen and Ruback (1983) argue that superior voting rights can increase job security, which in turn reduces the incentives of management to perform well. However, Hudson et al. (1992) contend that greater insider ownership gives management more incentives to improve firm performance. Given that the investor protections are relatively poor for the ADRs of the four Tiger Cub Economies, directors and officers of these firms may have incentive to expropriate minority shareholders' interest.

For audit quality, about $86 \%$ of the auditing companies are from the Big 4 accounting firms (BIG 4), Deloitte, Ernst \& Young (EY), KPMG, and PricewaterhouseCoopers (PwC). This indicates that most firms in our sample have relatively high credibility in their financial reports. With regard to firm characteristics and performance, the four Tiger Cub ADRs are well established, have good debt-paying ability, and they tend to perform well over the sample period. 
4.2 Differences in Corporate Governance and Firm Performance Between Pre-events and Post-events Tiger Cub ADRs

In this sub-section, we use T-tests to examine the impacts of the two events, cross-listing and SOX on corporate governance and firm performance of the four Tiger Cub ADRs. We report the comparisons of corporate governance and firm performance between pre-cross-listing and post-cross-listing ADRs in Table 5. It appears that ADRs from the Tiger Cub Economies exhibit an increase in the percentage of independent directors after listing their shares in the U.S. They also experience lower CEO duality and insider ownership after cross listing. Given that the investor protections are relatively poor for the ADRs of the four Tiger Cub Economies, directors and officers of these firms may expropriate minority shareholders' interest if they have disproportionate voting power. The decrease in insider ownership after cross-listing signals better corporate governance for these ADRs. Overall, corporate governance has been improved after cross listing. Our results show that the Tiger Cub firms try to bond themselves to the strict requirements in the U.S. markets by increasing the percentage of independent directors. Therefore, "bonding" becomes more apparent with an increase in separation between CEO and chairman (a decrease in CEO duality) and a decrease in insider ownership. In sum, consistent with bonding hypothesis, our results supports hypothesis 1a that Indonesian, Malaysian, Philippine, and Thailand's cross-listed firms exhibit an improvement in corporate governance after issuing ADRs.

Moreover, the post-ADR firm performance has declined as evidenced by a decrease in return on assets (ROA). This result thus goes against the bonding hypothesis and our hypothesis $1 \mathrm{~b}$ that Indonesian, Malaysian, Philippine, and Thailand's firms exhibit an improvement in firm performance after issuing ADRs. A closer examination of the sample firms reveals that about $78 \%$ of the ADRs in the sample are unsponsored Level I ADRs that the depositary banks can issue without the involvement or consent of the foreign issuers (Note 3). It is likely that firm performance suffered because many of these unsponsored Level I ADRs under study are in-voluntarily cross-listed by depositary banks and they face increased litigation risk in the U.S. as documented by Iliev et al. (2014).

Table 5. Difference in corporate governance and firm performance between pre-listing and post-listing ADRs

\begin{tabular}{|l|c|c|c|c|c|c|c|}
\hline Variable & \multicolumn{2}{|c|}{ Before ADR } & \multicolumn{2}{c|}{ After ADR } & & & \\
\hline & $\mathrm{N}$ & Mean & $\mathrm{N}$ & Mean & Diff & t Value & P-value \\
\hline Corporate governance & & & & & & & \\
\hline$\quad$ Board size & 455 & 10.01 & 335 & 9.78 & 0.22 & 0.86 & 0.39 \\
\hline Indep ratio & 451 & 0.36 & 328 & 0.39 & -0.03 & $-3.24 * * *$ & 0.001 \\
\hline CEO duality & 462 & 0.14 & 343 & 0.09 & 0.05 & $2.07 * *$ & 0.04 \\
\hline CEO education & 392 & 0.56 & 318 & 0.54 & 0.02 & 0.62 & 0.53 \\
\hline Insider own & 275 & 0.11 & 270 & 0.08 & 0.03 & $2.01 * *$ & 0.05 \\
\hline $\begin{array}{l}\text { Big 4 } \\
\text { Corporate performance }\end{array}$ & 459 & 0.85 & 338 & 0.88 & -0.03 & -1.23 & 0.22 \\
\hline $\begin{array}{l}\text { ROA } \\
\text { Tobin's Q }\end{array}$ & 454 & 0.1 & 331 & 0.08 & 0.02 & $1.88 *$ & 0.06 \\
\hline
\end{tabular}




\section{MInstitute ${ }_{\text {Min }}^{\text {Macrothink }}$}

International Journal of Accounting and Financial Reporting

ISSN 2162-3082 2019, Vol. 9, No. 1

In Table 6, we examine the effects of Sarbanes-Oxley Act, which was enacted in 2002, on corporate governance and firm performance of the sample firms (Note 4). Contrary to the result documented by Valenti (2008), the results show that there is little discernible differences in corporate governance measures between pre-SOX and post-SOX ADRs. As mentioned earlier, $97.5 \%$ of the firms in this study are Level I ADRs. These Level I ADRs do not need to comply with the strict governance and disclosure requirements stipulated by SOX as their Level II and Level III counterparts do (Boubakri, et al., 2010). As a result, the effects of SOX on enhancing corporate governance measures of the four Tiger Cub ADRs are insignificant. Thus, our results do not support hypothesis 2a that Indonesian, Malaysian, Philippine, and Thailand's firms listing their shares as ADRs exhibit an improvement in corporate governance after SOX.

With respect to firm performance, the four Tiger Cub ADRs tend to experience an increase in performance after SOX, which is against the evidence proposed by Berger et al. (2005). The higher costs of compliance and disclosure associated with SOX do not lead to a decrease in firm performance as expected. The negative impacts of SOX on firm performance observed by other scholars are not found here because most of the sample firms are Level I ADRs that do not need to follow the strict rules and regulations required by SOX. The low SOX compliance costs coupled with the recovery from the dot-com bubble and 9/11 attacks may, at least in part, explain why there is an increase in firm performance for these ADRs. Therefore, our results do not support hypothesis $2 \mathrm{~b}$ that Indonesian, Malaysian, Philippine, and Thailand's cross-listed firms exhibit an improvement in firm performance after SOX.

Table 6. Differences in corporate governance and firm characteristics between Pre-SOX and Post-SOX ADRs

\begin{tabular}{|l|l|l|l|l|l|r|r|}
\hline Variable & \multicolumn{2}{|c|}{ Before SOX } & \multicolumn{2}{c|}{ After SOX } & & & \\
\hline & $\mathrm{N}$ & Mean & $\mathrm{N}$ & Mean & Diff & t Value & P-value \\
\hline Corporate governance & & & & & & & \\
\hline Board size & 18 & 10.67 & 59 & 10.22 & 0.45 & 0.62 & 0.54 \\
\hline Indep ratio & 18 & 0.39 & 59 & 0.37 & 0.02 & 0.30 & 0.77 \\
\hline CEO Duality & 23 & 0.22 & 63 & 0.06 & 0.15 & 1.65 & 0.11 \\
\hline CEO education & 17 & 0.59 & 51 & 0.61 & -0.02 & -0.14 & 0.89 \\
\hline Insider own & 11 & 0.15 & 33 & 0.11 & 0.03 & 0.45 & 0.66 \\
\hline Big 4 & 22 & 0.82 & 62 & 0.92 & -0.10 & -1.11 & 0.18 \\
\hline Firm performance & & & & & & & \\
\hline ROA & 24 & 0.05 & 57 & 0.10 & -0.04 & -2.66 & $* *$ \\
\hline Tobin's Q & 22 & 1.40 & 57 & 1.71 & -0.30 & -0.94 & 0.01 \\
\hline
\end{tabular}

\subsection{Regression Analysis}

Before conducting regression analysis, we check for potential multi-collinearity among explanatory variables. We estimate the correlations between the pairs of the explanatory variables and present results in Table 7. In general, the correlations are low between each pair of the variables and therefore do not pose any potential multi-collinearity problems. 
Table 7. Pearson correlation test

\begin{tabular}{|c|c|c|c|c|c|c|c|c|c|c|c|c|c|}
\hline & Board size & Indep ratio & & CEO Dus & ality & CEO educatio & & Insider own & & Big 4 & & Lnasset & Leverage \\
\hline Board size & 1.00 & & & & & & & & & & & & \\
\hline Indep ratio & $-0.09 * * *$ & 1.00 & & & & & & & & & & & \\
\hline CEO Duality & $0.06 *$ & -0.14 & $* * *$ & 1.00 & & & & & & & & & \\
\hline CEO education & -0.02 & 0.04 & & 0.02 & & 1.00 & & & & & & & \\
\hline Insider own & -0.03 & -0.09 & $* *$ & -0.03 & & $0.11 *$ & $* * *$ & 1.00 & & & & & \\
\hline Big 4 & $0.14 * * *$ & 0.09 & $* * *$ & -0.17 & $* * *$ & $0.09 *$ & *** & 0.04 & & 1.00 & & & \\
\hline Lnasset & 0.04 & 0.21 & *** & 0.01 & & 0.05 & & $0.47 *$ & **** & $0.10 *$ & $* * *$ & 1.00 & \\
\hline Leverage & 0.02 & -0.07 & $*$ & -0.02 & & 0.12 * & $* * *$ & $0.09 *$ & *** & 0.00 & & 0.02 & 1.00 \\
\hline
\end{tabular}

We begin by examining the effect of cross listing on firm performance of the four Tiger Cub ADRs using return on assets (ROA) as performance measure. Table 8 shows that ADR listing has negative impact on firm performance for models 1-5. This relationship is robust after controlling for a number of measures such as board structure, CEO characteristics, ownership structure, audit quality, firm characteristics, and year and year fixed effects. Thus, our results do not substantiate hypothesis $1 \mathrm{~b}$ and is inconsistent with bonding hypothesis proposed by Coffee (1999, 2002), and Stulz (1999).

Table 8. The effect of ADR listing on firm performance using ROA as performance measure

\begin{tabular}{|c|c|c|c|c|c|c|c|c|c|c|c|c|}
\hline Model & 1 & & 2 & & 3 & & 4 & & 5 & & 6 & \\
\hline Intercept & 0.0243 & & 0.0368 & & -0.0101 & & -0.0251 & & 0.0464 & & 0.0481 & \\
\hline \multicolumn{13}{|l|}{ Event } \\
\hline ADR & -0.0243 & $* *$ & -0.0216 & $* *$ & -0.0207 & $* *$ & -0.0255 & $* *$ & -0.0253 & $* * *$ & -0.0182 & \\
\hline \multicolumn{13}{|c|}{ Corporate governance } \\
\hline \multicolumn{13}{|l|}{ Board structure } \\
\hline Board size & & & -0.0004 & & & & & & & & -0.0015 & \\
\hline Indep ratio & & & -0.1018 & $* * *$ & & & & & & & -0.1129 & $* * *$ \\
\hline \multicolumn{13}{|l|}{ CEO characteristics } \\
\hline CEO Duality & & & & & 0.0460 & $* * *$ & & & & & 0.0189 & \\
\hline CEO edu & & & & & -0.0293 & $* * *$ & & & & & -0.0239 & $* *$ \\
\hline \multicolumn{13}{|l|}{ Onwership structure } \\
\hline Insider own & & & & & & & 0.0350 & & & & 0.0265 & \\
\hline \multicolumn{13}{|l|}{ Audit quality } \\
\hline Big 4 & & & & & & & & & -0.0236 & $*$ & -0.0593 & $* * *$ \\
\hline \multicolumn{13}{|l|}{ Firm characte ristics } \\
\hline Lnasset & 0.0080 & $* * *$ & 0.0091 & $* * *$ & 0.0102 & $* * *$ & 0.0104 & $* * *$ & 0.0081 & $* * *$ & 0.0120 & $* * *$ \\
\hline Leverage & -0.0329 & $* * *$ & -0.0318 & $* * *$ & -0.0360 & $* * *$ & -0.0294 & $* * *$ & -0.0332 & $* * *$ & -0.0291 & $* * *$ \\
\hline \multicolumn{13}{|l|}{ Control variables } \\
\hline Year dummy & Yes & & Yes & & Yes & & Yes & & Yes & & Yes & \\
\hline Industry dummy & Yes & & Yes & & Yes & & Yes & & Yes & & Yes & \\
\hline Adj. R-square & 0.2430 & & 0.2468 & & 0.2885 & & 0.2723 & & 0.2425 & & 0.3089 & \\
\hline No. of observations & 606 & & 577 & & 523 & & 413 & & 590 & & 387 & \\
\hline
\end{tabular}

Following the examination of the effect of cross listing on firm performance, we investigate the effect of SOX on the performance of the sample ADRs. As shown in Table 9, SOX appears to have little impacts on firm performance across all of the models, after controlling for corporate governance, firm characteristics, and other control variables. Therefore, our results do not affirm hypothesis $2 b$ that the four Tiger Cub ADRs experience an improvement in firm performance after SOX. 
Table 9. The effect of SOX on firm performance using ROA as performance measure

\begin{tabular}{|c|c|c|c|c|c|c|c|c|c|c|c|c|}
\hline Model & 1 & & 2 & & 3 & & 4 & & 5 & & 6 & \\
\hline Intercept & -0.0469 & & -0.0290 & & -0.0836 & & -0.0829 & & -0.0278 & & -0.0057 & \\
\hline \multicolumn{13}{|l|}{ Event } \\
\hline SOX & 0.0273 & & 0.0249 & & 0.0236 & & 0.0410 & & 0.0289 & & 0.0352 & \\
\hline \multicolumn{13}{|c|}{ Corporate governance } \\
\hline \multicolumn{13}{|l|}{ Board structure } \\
\hline Board size & & & 0.0000 & & & & & & & & -0.0018 & \\
\hline Indep ratio & & & -0.1029 & $* * *$ & & & & & & & -0.1071 & $* * *$ \\
\hline \multicolumn{13}{|l|}{ CEO characteristics } \\
\hline CEO Duality & & & & & 0.0509 & $* * *$ & & & & & 0.0215 & \\
\hline CEO edu & & & & & -0.0295 & $* * *$ & & & & & -0.0251 & $* * *$ \\
\hline \multicolumn{13}{|l|}{ Ownership structure } \\
\hline Insider own & & & & & & & 0.0396 & & & & 0.0358 & \\
\hline \multicolumn{13}{|l|}{ Audit quality } \\
\hline Big 4 & & & & & & & & & -0.0230 & $* *$ & -0.0568 & $* * *$ \\
\hline \multicolumn{13}{|l|}{ Firm characte ris tics } \\
\hline Lnasset & 0.0083 & $* * *$ & 0.0100 & $* * *$ & 0.0109 & $* * *$ & 0.0095 & $* * *$ & 0.0084 & $* * *$ & 0.0115 & $* * *$ \\
\hline Leverage & -0.0302 & $* * *$ & -0.0300 & $* * *$ & -0.0317 & $* * *$ & -0.0302 & $* * *$ & -0.0306 & $* * *$ & -0.0291 & $* * *$ \\
\hline \multicolumn{13}{|l|}{ Control variables } \\
\hline Year dummy & Yes & & Yes & & Yes & & Yes & & Yes & & Yes & \\
\hline Industry dummy & Yes & & Yes & & Yes & & Yes & & Yes & & Yes & \\
\hline Adj. R-square & 0.2188 & & 0.2238 & & 0.2633 & & 0.2682 & & 0.2171 & & 0.3049 & \\
\hline No. of observations & 681 & & 650 & & 589 & & 461 & & 661 & & 429 & \\
\hline
\end{tabular}

\subsection{Robustness Check}

For robustness check, we re-examine the effects of cross listing and SOX, respectively on the performance of the four Tiger Cub ADRs using Tobin's Q as an alternative of performance measure. In Table 10, we present the effect of ADR listing on firm performance. The results show that ADR listing has negative and significant impact on firm performance across all of the models (models 1-6). Again, the relationship is robust after controlling for other variables that may affect firm performance. Thus, our results do not support bonding hypothesis that cross-listed firms choose to bond themselves to the stringent listing requirements in the U.S. in order to increase firm performance.

Table 10. The Effect of ADR Listing on Firm Performance using Tobin's Q as Performance Measure

\begin{tabular}{|c|c|c|c|c|c|c|c|c|c|c|c|c|}
\hline Model & 1 & & 2 & & 3 & & 4 & & \multicolumn{2}{|c|}{5} & \multirow{2}{*}{$\begin{array}{c}6 \\
-7.1292\end{array}$} & \multirow[b]{2}{*}{ **** } \\
\hline Intercept & -6.2500 & ***** & -6.6845 & **** & -6.4757 & **** & -7.1235 & **** & -6.0598 & **** & & \\
\hline \multicolumn{13}{|l|}{ Event } \\
\hline ADR & -0.3337 & ** & -0.3870 & ** & -0.4213 & ** & -0.6369 & **** & -0.3907 & ** & -0.6688 & **** \\
\hline \multicolumn{13}{|c|}{ Corporate governance } \\
\hline \multicolumn{13}{|l|}{ Board structrue } \\
\hline Board size & & & -0.0136 & & & & & & & & -0.0173 & \\
\hline Indep ratio & & & -1.5628 & *** & & & & & & & -2.2718 & **** \\
\hline \multicolumn{13}{|l|}{ CEO characteristics } \\
\hline CEO Duality & & & & & 0.5641 & ** & & & & & 0.3490 & \\
\hline CEO education & & & & & -0.8562 & **** & & & & & -0.6152 & **** \\
\hline \multicolumn{13}{|l|}{ Ownership structure } \\
\hline Insider own & & & & & & & 1.6863 & **** & & & 1.1070 & ** \\
\hline \multicolumn{13}{|l|}{ Audit quality } \\
\hline $\operatorname{Big} 4$ & & & & & & & & & -0.2763 & & -0.2915 & \\
\hline \multicolumn{13}{|l|}{ Firm characteristics } \\
\hline Lnasset & 0.4281 & $* * *$ & 0.4877 & **** & 0.4593 & **** & 0.4820 & **** & 0.4347 & $* * *$ & 0.5557 & $* * *$ \\
\hline Leverage & -0.2050 & $* * *$ & -0.2260 & **** & -0.2085 & **** & -0.1319 & * & -0.2109 & $* * *$ & -0.1635 & * \\
\hline \multicolumn{13}{|l|}{ Control variables } \\
\hline Year dummy & Yes & & Yes & & Yes & & Yes & & Yes & & Yes & \\
\hline Industry dummy & Yes & & Yes & & Yes & & Yes & & Yes & & Yes & \\
\hline Adj. R-square & 0.2841 & & 0.3217 & & 0.3651 & & 0.3397 & & 0.2975 & & 0.4258 & \\
\hline No. of observations & 581 & & 552 & & 502 & & 399 & & 565 & & 373 & \\
\hline
\end{tabular}


In Table 11, we display the effect of SOX on firm performance using Tobin's Q as a proxy for performance measure. As expected, SOX does not appear to affect firm performance for all of the models, after controlling for corporate governance, firm characteristics and other variables. It reinstates our speculation that higher compliance and disclosure costs associated with SOX do not negatively affect the performance of the sample firms, which composed almost entirely of Level I ADRs without SOX compliance obligation.

Table 11. The effect of SOX on firm performance using Tobin's Q as performance measure

\begin{tabular}{|c|c|c|c|c|c|c|c|c|c|c|c|c|}
\hline Model & 1 & & 2 & & 3 & & 4 & & 5 & & 6 & \\
\hline Intercept & -6.8385 & $* * *$ & -7.2887 & $* * *$ & -7.2642 & $* * *$ & -7.4336 & $* * *$ & -6.7964 & $* * *$ & -8.4624 & *** \\
\hline \multicolumn{13}{|l|}{ Event } \\
\hline SOX & -0.3458 & & -0.4780 & & -0.4209 & & -0.7180 & & -0.3446 & & -0.0731 & \\
\hline \multicolumn{13}{|c|}{ Corporate governance } \\
\hline \multicolumn{13}{|c|}{ Board structure } \\
\hline Board size & & & -0.0050 & & & & & & & & -0.0111 & \\
\hline Indep ratio & & & -1.6996 & $* * *$ & & & & & & & -2.5473 & $* * *$ \\
\hline \multicolumn{13}{|l|}{ CEO characteristics } \\
\hline CEO Duality & & & & & 0.6489 & $* * *$ & & & & & 0.5028 & $*$ \\
\hline CEO education & & & & & -0.8232 & $* * *$ & & & & & -0.5608 & *** \\
\hline \multicolumn{13}{|l|}{ Ownership structure } \\
\hline Insider own & & & & & & & 1.7518 & $* * *$ & & & 1.2398 & $* *$ \\
\hline \multicolumn{13}{|l|}{ Audit quality } \\
\hline Big 4 & & & & & & & & & -0.1979 & & -0.0591 & \\
\hline \multicolumn{13}{|l|}{ Firm characteristics } \\
\hline Lnasset & 0.4515 & $* * *$ & 0.5126 & $* * *$ & 0.4895 & $* * *$ & 0.4917 & $* * *$ & 0.4583 & $* * *$ & 0.5730 & $* * *$ \\
\hline Leverage & -0.2173 & $* * *$ & -0.2385 & $* * *$ & -0.2277 & $* * *$ & -0.1793 & $* *$ & -0.2253 & $* * *$ & -0.2195 & $* *$ \\
\hline \multicolumn{13}{|l|}{ Control variables } \\
\hline Year dummy & Yes & & Yes & & Yes & & Yes & & Yes & & Yes & \\
\hline Industry dummy & Yes & & Yes & & Yes & & Yes & & Yes & & Yes & \\
\hline Adj. R-square & 0.2824 & & 0.3177 & & 0.3588 & & 0.3229 & & 0.2900 & & 0.4076 & \\
\hline No. of observations & 651 & & 620 & & 563 & & 443 & & 631 & & 411 & \\
\hline
\end{tabular}

\section{Conclusion}

This paper examines, whether and to what extent, cross listing and SOX may affect firm performance and corporate governance of the cross-listed firms from four Tiger Cub Economies. We find that these cross-listed sample ADRs tend to bond themselves to the stringent listing requirements in the U.S. in order to enhance corporate governance, which is consistent with the bonding hypothesis proposed by Coffee (1999, 2002), and Stulz (1999). However, we do not find that these firms exhibit an improvement in firm performance after ADR listing as bonding hypothesis suggested. Furthermore, there is little discernible improvement in corporate governance over the post-SOX period. Our result therefore does not support the post-SOX improvement in corporate board transparency proposed by Valenti (2008). Finally, we show that higher SOX compliance costs do not appear to decrease the performance of the Tiger Cub ADRs. On the contrary, our evidence shows that the post-SOX firm performance of these ADRs has increased, which contradicts the result suggested by Berger et al. (2005).

Existing studies regarding the effect of ADR listing on cross-listed firms tend to look at companies across various countries as a whole (Karolyi, 1998; Miller, 1999; Stulz, 1999; Coffee, 1999, 2002; Doidge et al., 2004). We contribute to the literature in that we focus on cross-listed firms from four Tiger Cub Economics where investor protections are poor, and we consider the types of ADR listing programs that may affect the degree of regulatory 
compliance in the U.S. Furthermore, we examine the differential impacts of ADR listing and SOX, respectively on corporate governance and firm performance of the ADRs under study.

Our findings suggest that ADR listing, compared with SOX, tends to have more pronounced impact on corporate governance improvement for the cross-listed sample firms. SOX does not appear to improve corporate governance and decrease firm performance as predicted by prior literature because Level I ADRs do not need to follow the strict rules and regulations required by SOX.

Overall, the improvements in corporate governance and firm performance of cross-listed firms, or the extent of "bonding" with more stringent rules and regulations in the U.S. may vary depending on the domiciles and the types of the ADRs. Our study highlights the fact that the impacts of strict rules and regulations in the U.S. are not necessarily uniformly applicable across cross-listed firms of varying countries of origin and ADR listing types.

\section{Acknowledgement}

We gratefully acknowledge the grants, services and facilities of the Computational Cluster at State University of New York (SUNY) Geneseo, funded by SUNY Investment and Performance Award.

\section{References}

Aggarwal, R., Cao, J., \& Chen, F. (2012). Information environment, dividend changes, and signaling: Evidence from ADR firms. Contemporary Accounting Research, 29(2), 403-431.

Alexander, G. J., Eun C. S., \& Janakiramanan, S. (1988). International listings and stock returns: Some empirical evidence. Journal of Financial and Quantitative Analysis, 23(2), 135-151.

Alice, O., Andrews, T., \& Welbourne, M. (2000). The People/Performance Balance in IPO firms: The Effect of the Chief Executive Officer's financial Orientation. Entrepreneurship Theory and Practice, 25(1), 93-107.

Baker, H. K., Nofsinger, J. R., \& Weaver, D. G. (2002). International cross-listing and visibility. Journal of Financial and Quantitative Analysis, 37(3), 495-521.

Ball, R., Hail, L., \& Vasvari, F. (2018). Equity cross-listings in the U.S. and the price of debt. Review of Accounting Studies, 23(2), 385-421.

Baliga, B. R., Moyer, R.C., \& Rao, R.S. (1996). CEO duality and firm performance: What's the fuss?. Strategic Management Journal, 17, 41-53.

Benos, E., \& Weisbach, M. S. (2004). Private benefits and cross-listings in the United States. Emerging Markets Review, 5(2), 217-240.

Berger, P. G., Li, F., \& Wong, M. H. F. (2005). The impact of Sarbanes-Oxley on cross-listed companies. Working paper, University of Chicago and University of Michigan. 
Boubakri, N., Cossett, J. C., \& Samet, A. (2010). The choice of ADRs. Journal of Banking and Finance, 34(9), 2077-2095.

Brickley, J., Coles, J., \& Jarrell, G. (1997). Leadership Structure: Separating the CEO and Chairman of the Board. Journal of Corporate Finance, 4, 189-220.

Coffee, J. C. (1999). The future as history: The prospects for global convergence and its implications. Northwestern Law Review, 93, 641-708.

Coffee, J. C. (2002). Racing towards the top? The impact of cross-listings and stock market competition on international corporate governance. Columbia Law Review, 102(7), $1757-1831$.

Coles, J., Daniel, N., \& Naveen, L. (2008). Boards: does one size fit all?. Journal of Financial Economics, 87, 329-356.

Doidge, C. (2004). U.S. cross-listings and the private benefits of control: Evidence from dual-class firms. Journal of Financial Economics, 72, 519-553.

Doidge, C., Karolyi, A., \& Stulz, R. M. (2004). Why are foreign firms listed in the US worth more?. Journal of Financial Economics, 71, 205-238.

Doidge, C. A., Karolyi, G. A., \& Stulz, R. M. (2009). Has New York become less competitive than London in global markets? Evaluating foreign listing choices over time. Journal of Financial Economics, 91, 253-277.

Domowitz, I., Glen, J., \& Madhavan, A. (1997). Market segmentation and stock prices: evidence from an emerging market. Journal of Finance, 52, 1059-1085.

Eaton, T. V., Nofsinger, J. R., \& Weaver, D. G. (2007). Disclosure and the cost of equity in international cross-listing. Review of Quantitative Finance and Accounting, 29, 1-24.

Foerster, S. R., \& Karolyi, G. A. (1999). The effects of market segmentation and investor recognition on asset prices: Evidence from foreign stocks listing in the United States. Journal of Finance, 54(3), 981-1013.

Hudson, C., Jahera, J., \& Lloyd, W. (1992). Further Evidence on the Relationship Between Ownership and Performance. The Financial Review, 27, 227-239.

Iliev P., Miller, D. P., \& Roth, L. (2014). Uninvited U.S. investors? Economic consequences of involuntary cross-listings. Journal of Accounting Research, 52(2), 473-519.

Jensen, M. C., \& Ruback R. S. (1983). The market for corporate control: The scientific evidence. Journal of Financial Economics, 11(1-4), 5-50.

Karolyi, A. (1998). Why Do Companies List Shares Abroad: A Survey of the Evidence and Its Managerial Implications. Financial Markets, Institutions and Instruments, 7, 1-60.

Karolyi, G. A. (2006). The world of cross-listings and cross-listings of the world: Challenging conventional wisdom. Review of Finance, 10(1), 99-152. 
La Porta, R., Lopez-de-Silanes, F., Shleifer, A., \& Vishny, R. W. (1998). Law and finance. Journal of Political Economy, 106(6), 1113-1155.

La Porta, R., Lopez-de-Silanes, F., Shleifer, A., \& Vishny, R. W. (2000). Investor protection and corporate governance. Journal of Financial Economics, 58, 3-27.

La Porta, R., Lopez-de-Silanes, F., \& Shleifer, A. (2008). The economic consequences of legal origins. Journal of Economic Literature, 46(2), 285-332.

Lang, M. H., Lins, K. V., \& Miller, D. P. (2003). Does cross listing in the United States improve a firm's information environment and increase market value. Journal of Accounting Research, 41(2), 317-345.

Lee, H. W., \& Valero, M. (2010). Cross-listing effect on information environment of foreign firms: ADR type and country characteristics. Journal of Multinational Financial Management, 20, 178-196.

Lel, U., \& Miller, D. P. (2008). International cross-listing, firm performance, and top management turnover: a test of the bonding hypothesis. Journal of Finance, 63, 1897-1937.

Licht, A. N. (2003). Cross-listing and corporate governance: Bonding or avoiding?. Chicago Journal of International Law, 4(1), 141-163.

Licht, A. N., Poliquin, C., Siegel, J. I., \& Li, X. (2018). What makes the bonding stick? A natural experiment testing the legal bonding hypothesis. Journal of Financial Economics, 129, 329-356.

Lipton, M., \& Lorsch, J. W. (1992). A modest proposal for improved corporate governance. Business Lawyer, 48(1), 59-77.

Merton, R. C. (1987). A simple model of capital market equilibrium incomplete information. The Journal of Finance, 42(3), 483-510.

Miller, P. (1999). The market reaction to international cross-listings: evidence from Depositary Receipts. Journal of Financial Economics, 51(1), 103-123.

Pagano, M., Röell, A. A., \& Zechner, J. (2002). The geography of equity listing: Why do companies list abroad?. The Journal of Finance, 57(6), 2651-2694.

Reese, W., \& Weisbach, M. (2002). Protection of minority shareholder interests, cross listings in the United States, and subsequent equity offerings. Journal of Financial Economics, 66, 65-104.

Siegel, J. (2005). Can foreign firms bond themselves effectively by renting U.S. securities laws?. Journal of Financial Economics, 75, 319-359.

Stulz, R. M. (1999). Globalization of equity markets and the cost of capital. Journal of Applied Corporate Finance, 12, 8-25.

Valenti, A. (2008). The Sarbanes-Oxley Act of 2002: has it brought about changes in the boards of large U.S. corporations?. Journal of Business Ethics, 81, 401-412. 


\section{Mll Macrothink}

International Journal of Accounting and Financial Reporting

ISSN 2162-3082

2019, Vol. 9, No. 1

Wójcik, D., Clark, G. L., \& Bauer, R. (2005). Corporate governance and cross-listing: Evidence from European companies. Unpublished Working Paper, University of Oxford.

\section{Notes}

Note 1. There are four types of ADRs: Level I, Level II, Level III, and Rule 144A. Level III and Rule 144A ADRs are allowed for capital-raising, whereas Level I and Level II ADRs are allowed to circulate their shares on secondary markets without raising new capital. Moreover, these four types of ADRs vary according to the degrees of their compliance with regulatory rules and disclosure requirements. Level II and Level III ADRs are subject to more stringent rules and regulations, whereas Level I and Rule 144A are not (Page 3).

Note 2. Results using a full sample that includes Levels I, II, and III ADRs, and sub-sample that covers only Level I ADRs are the similar across all the tables in this paper. For brevity, we report the results based on the full sample (Page 7).

Note 3. Depositary banks retain full control over the unsponsored ADRs, while the foreign issuers have no control over unsponsored ADRs. In particular, depositary banks are not required to obtain permission or consult with foreign issuers before registering unsponsored ADRs with SEC, neither are they required to extend the benefits and voting rights to the shareholders of the unsponsored ADRs (Page 10).

Note 4. Results are based on the comparisons in corporate governance and firm performance during $(-2,+2)$ event window (Page 11).

\section{Copyright Disclaimer}

Copyright for this article is retained by the author(s), with first publication rights granted to the journal.

This is an open-access article distributed under the terms and conditions of the Creative Commons Attribution license (http://creativecommons.org/licenses/by/4.0/) 